\title{
IDENTIFIKASI SISWA DALAM MENYELSAIKAN MASALAH PADA MATA KULIAH KALKULUS LANJUTAN
}

\author{
Zetriuslita, Leo Adhar Effendi, Rezi Ariawan \\ Pendidikan Matematika Universitas Islam Riau \\ Email: zetri.lita@gmail.com
}

\begin{abstract}
Abstrak. Penelitian ini bertujuan untuk mengidentifikasi jenis kesalahan yang dilakukan oleh siswa dalam memecahkan masalah dalam mata kuliah kalkulus lanjutan. Pengumpulan data dilakukan dengan teknik tes. Penelitian ini merupakan penelitian deskriptif kualitatif. Tes diberikan kepada mahasiswa semester 3, yang berjumlah 19 orang. Berdasarkan hasil penelitian, ditemukan bahwa pada masalah nomor 1, kesalahan yang paling umum adalah 68,42\% (13 orang) dan kesalahan paling kecil adalah 21,05\% (4 orang). Pada soal nomor 2, jenis kesalahan yang paling umum adalah 73,68\% (14 orang) dan kesalahan terkecil adalah kesalahan operasi dan fakta yaitu 0\% (19 orang). Untuk pertanyaan nomor 3, jenis kesalahan yang paling umum adalah kesalahan konsep 0\% (19 orang) dan kesalahan terkecil adalah kesalahan operasi adalah 0\% (19 orang). Pada pertanyaan nomor 4, jenis kesalahan yang paling sering dilakukan oleh siswa adalah konsep kesalahan yaitu 47, 37\% (9 orang) dan jenis kesalahan yang paling sedikit dilakukan adalah operasi kesahan dan fakta yaitu 0\% (19 orang) ). Secara keseluruhan jenis kesalahan yang paling banyak dilakukan oleh siswa dalam menyelesaikan soal kalkulus lanjutan adalah kesalahan konsep yaitu sebanyak 56,58\% dan jenis kesalahan yang paling sedikit dilakukan adalah kesalahan operasi yaitu sebanyak 5,26\%.
\end{abstract}

Kata Kunci: jenis kesalahan matematika, kalkulus lanjutan

\section{PENDAHULUAN}

Makalah Fakultas Keguruan dan Ilmu Pendidikan (FKIP) Universitas Islam Riau (UIR) merupakan salah satu lembaga pendidikan yang menghasilkan calon guru ataupun tenaga kependidikan. Fakultas ini memiliki 7 program studi, yaitu program studi Pendidikan Bahasa Indonesia, Pendidikan Bahasa Inggris, Pendidikan Sendratasik, Pendidikan Matematika, Pendidikan Biologi, Pendidikan Penjaskesrek, dan Pendidikan Akuntansi. Kurikulum FKIP UIR, khususnya program studi Pendidikan Matematika terdiri dari kelompok Mata Kuliah Umum (MKU), Mata Kuliah Dasar Profesi Pendidikan (MKDPP), Mata Kuliah Keahlian Profesi Pendidikan Fakultas (MKKPPF), Mata Kuliah Keahlian Profesi Pendidikan Prodi (MKKPPP), Mata Kuliah Keahlian Keilmuan Prodi (MKKKP), dan kelompok Mata Kuliah Keahlian Keilmuan Pilihan Prodi (MKKKPP).

Seluruh mata kuliah dalam kelompok mata kuliah keahlian keilmuan prodi merupakan mata kuliah yang wajib diikuti oleh semua mahasiswa program studi Pendidikan Matematika. Salah satu mata kuliah yang termasuk ke dalam kelompok mata kuliah tersebut yaitu mata kuliah Kalkulus Lanjutan. Mata kuliah ini banyak melibatkan ide-ide matematika, seperti aljabar dan trigonometri, kalkulus diferensial, kalkulus integral, dan geometri analitik bidang dan ruang. Oleh sebab itu, untuk dapat mempelajari mata kuliah Kalkulus Lanjutan diperlukan mata kuliah lain sebagai prasyarat.

Kalkulus lanjutan merupakan mata kuliah wajib Program Studi Pendidikan Matematika. Mata kuliah ini juga menjadi mata kuliah prasyarat untuk mengikuti mata kuliah persamaan differensial dan statistik matematika. Mata kuliah kalkulus lanjutan mempunyai beberapa mata kuliah prasyarat, yaitu mata kuliah kalkulus I, kalkulus II, dan geometri analitik. Mata kuliah geometri analitik digunakan sebagai ilmu dasar bagi mahasiswa untuk menggambar benda pejal pada ruang dimensi tiga ketika akan mencari volume ataupun luas permukaan ataupun perhitungan pengintegralan yang lainnya. Mata kuliah kalkulus I dan II yang terkait dengan limit, diferensial, penghitungan integralnya baik pada saat mencari volume, luas permukaan ataupun perhitungan lainnya. Pada mata kuliah kalkulus lanjutan, mahasiswa dituntut untuk mampu menganalisis, mengaitkan dan menggunakan konsep yang telah dipelajari pada kalkulus I, kalkulus II dan geometri analitik.

Dalam perkuliahan mata kuliah ini, dosen langsung menyampaikan dan menjelaskan konsep kepada mahasiswa, memberikan contoh soal, meminta mahasiswa mengerjakan soal latihan, kemudian meminta beberapa mahasiswa menyelesaikan soal di papan tulis. Namun faktanya, pada mata kuliah ini banyak mahasiswa yang mengalami kesulitan dalam penyelesaian soal, sehingga kesalahan itu terulang pada penyelesaian soal ujian. Kesalahan ini menyebabkan nilai mahasiswa yang mengikuti mata kuliah ini belum memuaskan.

Kesalahan yang dilakukan oleh mahasiswa perlu diidentifikasi, sehingga dapat dikeahui apa saja jenis kesalahan yang dilakukan oleh mahasiswa. Dengan mengetahui jenis kesalahan yang dilakukan maka dapat dicari alternatif pemecahannya sehingga kesalahan 
tersebut dapat dikurangi, sehingga mahasiswa tidak melakukan kesalahan yang sama apabila menjumpai soal yang sejenis. Dampak jangka panjang yang dapat diperoleh adalah jika suatu kesalahan sudah diperbaiki maka kesalahan tersebut tidak akan berlanjut ke materi berikutya yang berhubungan dengan materi kalkulus lanjutan, misalnya pada mata kuliah persamaan diferensial dan statistik matematika.

\section{METODE}

Penelitian yang digunakan dalam penelitian ini adalah deskriptif. Menurut Sukmadinata (2011) penelitian deskriptif adalah suatu bentuk penelitian yang paling dasar, yang ditujukan untuk mendeskripsikan atau menggambarkan fenomena-fenomena yang ada, baik fenomena yang bersifat alamiah maupun rekayasa manusia. Penelitian deskriptif dapat juga ditujukan untuk mengadakan kajian yang bersifat kualitatif. Penelitian deskriptif tidak memberikan perlakuan atau pengubahan pada variabel-variabel bebeas, tetapi menggambarkan suatu kondisi apa adanya. Artinya peneliti tidak melakukan manipulasi atau memberikan perlakuan tertentu terhadap variabel atau merancang sesuatu yang yang diharapkan terjadi pada variabel, tetapi semua kegiatan, keadaan, kejadian, aspek, komponen atau variabel berjalan sebagaimana adanya. Satu-satunya unsur manipulasi atau perlakuan yang yang diberikan hanyalah penelitian itu sendiri, yang dilakukan melalui observasi, wawancara, pengedaran angket atau studi dokumentasi.

Senanda dengan pendapat di atas, Bogdan dan Biklen dalam Emzir (2012) menyatakan bahwa terdapat lima ciri utama penelitian kualitatif, yaitu; (1) naturalistik: memiliki latar aktual sebagai sumber langsung data dan peneliti merupakan instrumen kunci; (2) data deskriptif: data yang dikumpulkan lebih mengambil bentuk kata-kata atau gambar-gambar daripada angka-angka; (3) berurusan dengan proses: penelitian kualtitatif lebih menekankan kepada proses daripada hasil atau produk; (4) induktif: penelitian kualitatif cenderung menganalisis data secara induktif, dan tidak melakukan pencarian di luar data atau bukti untuk menolak sebuah hipotesis.

Berdasarkan beberapa pendapat di atas , maka pendekatan penelitian ini adalah penelitian kualitatif. Disebut penelitian kualitatif karena prosedur penelitiannya menghasilkan data deskriptif berupa katakata tertulis atau lisan dari orang-orang atau tentang perilaku yang diamati.

Subyek dalam penelitian ini adalah mahasiswa program studi pendidikan matematika yang berjumlah sebanyak 19 orang, dimana mereka sedang mengikuti mata kuliah kalkulus lanjutan pada tahun ajaran
2014/2015.

Instrumen yang akan digunakan dalam penelitian ini berupa soal uraian. Dipilihnya tes berbentuk uraian tersebut, karena dengan tes berbentuk uraian dapat diketahui proses pengerjaan mahasiswa dalam menyelesaikan soal. Dengan demikian, diharapkan dapat dengan tepat diidentifikasi jenis kesalahannya

\section{HASIL DAN PEMBAHASAN}

Pada tabel 1 di bawah ini dideskripsikan jumlah dan persentase mahasiswa yang melakukan kesalahan dalam menyelesaikan soal-soal pada mata kuliah kalkulus lanjutan

Tabel 1. Rekapitulasi Jumlah dan Persentase Mahasiswa ditinjau dari Jenis Kesalahan dan Soal

\begin{tabular}{|c|c|c|c|c|}
\hline \multirow{2}{*}{$\begin{array}{c}\text { Nomor } \\
\text { Soal }\end{array}$} & \multicolumn{4}{|c|}{ Jenis Kesalahan } \\
\hline & Fakta & Konsep & Operasi & Prinsip \\
\hline 1 & $\begin{array}{c}6 \text { orang } \\
(31,58 \%)\end{array}$ & $\begin{array}{c}13 \text { orang } \\
(68,42 \%)\end{array}$ & $\begin{array}{c}4 \text { orang } \\
(21,05 \%)\end{array}$ & $\begin{array}{l}9 \text { orang } \\
(47,3 \%)\end{array}$ \\
\hline 2 & $\begin{array}{c}0 \text { orang } \\
(0 \%)\end{array}$ & $\begin{array}{c}2 \text { orang } \\
(10,53 \%)\end{array}$ & $\begin{array}{c}0 \text { orang } \\
(0 \%)\end{array}$ & $\begin{array}{r}14 \text { orang } \\
(73,68 \%)\end{array}$ \\
\hline 3 & $\begin{array}{c}2 \text { orang } \\
(10,53 \%)\end{array}$ & $\begin{array}{l}19 \text { orang } \\
(100 \%)\end{array}$ & $\begin{array}{c}\text { 0 orang } \\
(0 \%)\end{array}$ & $\begin{array}{l}1 \text { orang } \\
(5,26 \%)\end{array}$ \\
\hline 4 & $\begin{array}{c}0 \text { orang } \\
(0 \%)\end{array}$ & $\begin{array}{l}9 \text { orang } \\
(47,3 \%)\end{array}$ & $\begin{array}{c}0 \text { orang } \\
(0 \%)\end{array}$ & $\begin{array}{c}8 \text { orang } \\
(42,10 \%)\end{array}$ \\
\hline Total & $\begin{array}{c}\text { 8orang } \\
(10,53 \%)\end{array}$ & $\begin{array}{l}\text { 43orang } \\
(56,58 \%)\end{array}$ & $\begin{array}{l}\text { 4orang } \\
(5,26 \%)\end{array}$ & $\begin{array}{l}\text { 32 orang } \\
(42,10 \%)\end{array}$ \\
\hline
\end{tabular}

Temuan peneliti menunjukkan bahwa jenis kesalahan yang paling banyak dilakukan oleh peserta didik dalam menyelesaikan soal pada mata kuliah kalkulus lanjutan adalah jenis kesalahan konsep. Sedangkan jenis kesalahan yang paling sedikit dilakukan oleh peserta didik adalah jenis kesalahan operasi.

Untuk menganalis mengapa jenis kesalahan konsep yang paling banyak dilakukan oleh peserta didik, maka terlebih dahulu kita mengingat kembali defenisi kesalahan konsep yang telah peneliti paparkan di bagaian depan. Konsep adalah ide abstrak yang digunakan untuk menggolongkan atau mengklasifikasi sekumpulan objek tertentu dalam prosesnya diperlukan kemampuan untuk mengorganisasikan informasi yang diterima oleh peserta didik untuk kemudian digunakan untuk menyelesaikan masalah. Kesalahan konsep merupakan kesalahan peserta didik dalam menguasai dan menggunakan konsep-konsep tertentu untuk menyelesaikan suatu masalah.

Berdasarkan analisa terhadap lembar jawaban peserta didik tersebut, kesalahan konsep yang dilakukan oleh peserta didik pada soal nomor 1 lebih disebabkan oleh kesalahan mahasiswa dalam 
menyatakan rumus atau konsep luas yang akan digunakan untuk menyelesaikan soal yang disajikan. Konsep luas yang seharusnya digunakan untuk menyelesaikan persoalan yang disajikan yaitu $L=$ $\frac{1}{2} \int_{0}^{\pi / 2}(4 \sin 2 \theta)^{2} d \theta$, yang dinyatakan oleh peserta didik yaitu $L=2 \int 4 \sin 2 \theta$.

Selanjutnya kesalahan konsep yang dilakukan oleh peserta didik untuk soal nomor 2 lebih disebabkan ketidak pahaman peserta didik terhadap konsep jejak di $\mathrm{R}^{3}$. Peserta didik membuat jejaknya pada bidang $\mathrm{YOZ}$, sehingga $\mathrm{y}=0$, seharusnya di $\mathrm{R}^{3}, \mathrm{Z}$ $=0$.

Pada soal nomor 3, kesalahan konsep yang dilakukan dapat di identifikasi menjadi beberapa, diantaranya yaitu: (a) salah dalam menggunakan konsep turunan. Konsep turunan yang seharusnya digunakan adalah konsep turunan dengan menggunakan aturan rantai. Jawaban yang ditulis peserta didik yaitu $\frac{\delta f}{\delta x}=\sin \left(\mathrm{UV}^{\prime}+\mathrm{VU}^{\prime}\right)$, seharusnya $\frac{\delta f}{\delta x}=\left(\mathrm{UV}^{\prime}+\mathrm{VU}^{\prime}\right)$; (b) kesalahan konsep selanjutnya adalah kesalahan dalam menurunkan fungsi $f(x)=\sin$ x. Peserta didik menyatakan turunan dari fungsi tersebut adalah $f(x)=$ $\cos x$, seharusnya turunan dari fungsi tersebut adalah $f(x)=\cos x$, (c) Peserta didik salah dalam menentukan turunan dari $f(x, y)=x \sin \left(x^{2}-2 y\right)$. Peserta didik menyatakan turunan dari fungsi tersebut adalah $\frac{\delta f}{\delta x}=\sin (2 x-2 y)$, jawaban seharusnya untuk turunan dari fungsi tersebut adalah $\sin \left(x^{2}-2 y\right)+$ $2 x \cos \left(x^{2}-2 y\right)$.

Kesalahan konsep berikutnya yang dilakukan oleh peserta didik pada soal nomor 4 , juga dapat diidentifikasi dalam beberapa bentuk kesalahan konsep, diantaranya yaitu; (a) salah dalam menggunakan konsep integral. Peserta didik menyatakan integral dari $\int\left(x^{2}+y^{2}\right) d x=2 x+$ $y^{2}$, jawaban tersebut masih salah. Hal ini mengindikasikan peserta didik belum menguasai sepenuhnya materi ajar pada perkuliahan kalkulus 2, karena dikalkulus 2 sudah diajarkan bagaimana menggunakan dan menyelesaikan permasalahan dengan menggunakan integral. Jawaban yang benar untuk permasalahan tersebut adalah $\int\left(x^{2}+\right.$ $\left.y^{2}\right) d x=\frac{1}{3} x^{3}+x y^{2}+c$; (b) kesalahan konsep berikutnya adalah salah dalam menggunakan rumus integral untuk menentukan volume dengan pendekatan integral. Yang dinyatakan oleh peserta didik rumus volume integral untuk permasalahan yang disajikan adalah $\quad V=\int_{0}^{\pi / 4} \int_{0}^{2} r^{2} r d r d \theta$, seharusnya rumus integral yang digunakan untuk menyelesaikan permasalahan tersebut adalah $V=$ $4 \int_{0}^{\pi / 2} \int_{0}^{2} r^{2} r d r d \theta$; (c) selanjutnya kesalahan konsep yang ditemukan pada lembar jawaban peserta didik pada soal nomor 4 adalah salah dalam menyatakan rumus volume untuk permasalahan yang disajikan. Rumus volume yang dinyatakan oleh peserta didik yaitu $V=\int_{0}^{0} \int_{0}^{2}\left(x^{2}+y^{2}\right)^{2} d x d y$. Rumus volume yang seharusnya digunakan untuk menyelesaikan permasalahan yang diberikan adalah $V=4 \int_{0}^{2} \int_{0}^{\sqrt{4-y^{2}}} x^{2}+y^{2} d x d y$.

Secara umum, kesalahan konsep yang dilakukan oleh peserta didik lebih disebabkan oleh belum menguasai secara utuh konsep atau pengetahuan yang diperlukan untuk menyelesaikan permasalahan pada kalkulus lanjutan, misalnya konsep aturan turunan dan integral. Selanjutnya kesalahan konsep yang dilakukan oleh peserta didik disebabkan oleh mereka belum menguasai materi ajar kalkulus lanjutan secara utuh. Sehingga rumus-rumus integral yang akan digunakan untuk menyelesaikan permasalahan yang disajikan masih salah.

Sedangkan kesalahan yang paling sedikit dilakukan oleh peserta adalah kesalahan operasi. Berdasarkan analisa peneliti, kesalahan operasi lebih disebabkan kurang telitinya peserta didik dalam menyatakan selesaian dari permasalahan yang disajikan. Selanjutnya kesalahan operasi disebabkan juga oleh kondisi buru-buru ingin cepat menuntaskan soal tersebut.

Implikasi dari penelitian ini adalah, karena kesalahan konsep yang paling dominan dilakukan oleh peserta didik dalam menyelesaikan permasalahan kalkulus lanjutan, maka pemahaman konsep dan penguasaan konsep terhadap materi pendukung dan kalkulus lanjutan itu sendiri harus mendapat perhatian serius, misalnya dengan mengadakan perubahan pola, pendekatan dan metode pembelajaran.

\section{SIMPULAN}

Jenis kesalahan yang paling banyak dilakukan oleh peserta didik dalam menyelesaikan permasalahan kalkulus lanjutan adalah kesalahan konsep, yaitu $56,58 \%$, artinya lebih dari setengah subyek penelitian melakukan kesalahan konsep. Jenis kesalahan yang paling sedikit dilakukan oleh peserta didk dalam menyelesaikan permasalahan kalkulus lanjutan adalah kesalahan operasi, yaitu sebanyak 5,26\%, artinya sebanyak $94,74 \%$ peserta didik tidak melakukan kesalahan operasi.

Saran peneliti kepada pembaca yang ingin 
melanjutkan kajian ini, diantaranya:

1. Perlu dilakukan penelitian lanjutan tentang apa penyebab dari mengapa paling dominannya kesalahan konsep yang dilakukan oleh peserta didik. Karena dalam penelitian ini tidak dilengkapi dengan wawancara terhadap peserta didik, maka untuk mendapatkan informasi yang utuh, harus dilakukan wawancara terhadap peserta didik.

2. Perlu dilakukan tes awal terlebih dahulu terkait kemampuan materi prasyarat untuk mata kuliah kalkulus lanjutan. Hal ini dilakukan untuk mengantisipasi supaya kemampuan prasyarat mahasiswa tidak menjadi faktor kendalanya.

Penelitian ini diharapkan dapat menjadi landasan berpijak para pengajar untuk menentukan gaya mengajar di kelas.

\section{DAFTAR PUSTAKA}

Abdurrahman, M. (2003). Pendidikan bagi Anak Berkesulitan Belajar. Jakarta: Rineka Cipta.

Dahar, R.W. (1996). Teori-teori Belajar. Jakarta : Erlangga.

Emzir .(2012). Metodologi Penelitian Kualitatif (Analisis Data). Jakarta: Rajawali Pers.

FKIP UIR. (2014). Buku Pedoman Akademik Tahun Akademik 2013/2014. Pekanbaru: FKIP UIR.

Gagne, R.M., Briggs, L.J. and Wager, W.W. (1992). Principles of Instructional Design (fourth edition). Orlando: Holt, Rinehart \& Winstone, Inc.

Hallen. (2005). Bimbingan dan Konseling. Jakarta: Quantum Teaching.

Kirkley, J. (2003). Principles for Teaching Problem Solving. Copyright Plato Learning, Inc.
Kusumah, Y.S. (2008). "Konsep, Pengembangan, dan Implementasi Computer-Based Learning dalam Peningkatan Kemampuan High-Order Mathematical Thinking". Disampaikan pada Pidato Pengukuhan Guru Besar. Bandung: UPI.

Lexy J. M. (2014). Metode Penelitian Kualitatif Edisi Revisi. Bandung: Rosdakarya.

Nasution, N. (1992). Psikologi Pendidikan. Jakarta: Depdikbud.

Polya, G. (1985). How to Solve it. A new Aspect of Mathematical Method, Second Edition. New Jersey: Princenton University Press.

Rahmat, B,Sugiarto, B dan Pramesti, G. (2013). Analisis Kesalahan Siswa dalam Menyelesaikan Soal Pada Materi Ruang Dimensi Tiga Ditinjau dari Gaya Kognitif Siswa (Penelitian dilakukan di SMA Negeri 7 Surakarta kelas X Tahun Ajaran 2011/2012). Jurnal Pendidikan Matematika Solusi Vol. 1 No. 1 Maret 2013

Sukmadinata, N.S. (2011). Metode Penelitian Pendidikan. Bandung: Rosdakarya.

Suryabrata, S. (2014). Metodologi Penelitian. Jakarta: PT. Raja Grafindo Persada.

Ulifa, S.N (2014). Hasil Analisis Kesalahan Siswa dalam Menyelesaikan Soal Matematika Pada Materi Relasi. Jurnal Pendidikan Matematika STKIP PGRI Sidoarjo Vol.2 No. 1, Maret 2014. ISSN: 2337-8166

Undang-undang Republik Indonesia Nomor 14 Tahun 2005 Tentang Guru dan Dosen. 